\title{
DETERMINATION OF PREVALENCE RATE OF ENTAMOEBA HISTOLYTICA AMONG CHILDREN DIAGNOSED WITH ACUTE DIARRHEA IN KANO, NIGERIA
}

\author{
JA'AFAR S ADAM ${ }^{1}$, MUSA G YAHAYA ${ }^{2}$, FAROUK S NAS ${ }^{3}$, LURWAN MU'AZU ${ }^{4}$, MUHAMMAD ALI ${ }^{5 *}$
}

${ }^{1}$ Department of Pharmaceutical Technology, School of Technology, Kano State Polytechnics, Nigeria, ${ }^{2}$ Biology Unit, Ahmadu Bello University, School of Basic and Remedial Studies Funtua, Nigeria, ${ }^{3}$ Department of Biological Sciences, Bayero University Kano, Nigeria, ${ }^{4}$ Department of Biological Sciences, Federal University, Gusau, Nigeria, ${ }^{5}$ Department of Microbiology, Federal University, Gusau, Nigeria. Email: alimuhd4real@gmail.com

Received: 28 November 2020, Revised and Accepted: 26 December 2020

\section{ABSTRACT}

Objective: The study was aimed to determine the prevalence of Entamoeba histolytica among children diagnosed with acute diarrhea in Kura General Hospital Kano, from February to August 2017.

Methods: A total of 236 stools samples were collected from children within the age group of 0-5 years diagnosed with acute diarrhea attending the hospital. The stool samples were examined for E. histolytica cysts and trophozoites using direct wet preparation and formol-ether concentration techniques.

Results: The result showed that 23 samples which accounted for $9.75 \%$ of the samples were found to be positive for the parasite. Highest incidence of the parasite was found among children within the age category of 4-5 years. The results also indicated that males (56.5\%) were more infected than females (43.5\%). However, there is no statistical difference in the rate of infection among the sex and age group of the patients at $\mathrm{p}<0.05$.

Conclusion: Maintenance of personal hygiene and improved sanitation of the environment will indeed prevent contamination of food and water sources.

\section{INTRODUCTION}

More than $50 \%$ of the world populations are infested with helminthes and protozoans [1]. Most people are asymptomatic to these infections but certain intestinal parasites may cause diarrhea and other related diseases [2]. Amoebiasis is a medical condition due to infection by protozoan parasite called Entamoeba histolytica. The organism is considered as the invasive type due to its intestinal tissue dissolving carnivorous potential, thus of medical importance [3] Intestinal amoebiasis due to E. histolytica was ranked third among parasitic protozoan infection leading to death after malaria and schistosomiasis [4]. Transmission of the infection includes unsanitary habits, contamination of food and water by human feces already infected with the parasite as well as direct fecal-oral contact [5]. About $10 \%$ of infected individuals show clinical symptoms, which occur with invasive amoebiasis which though over 48 million people annually. Majority of symptomatic patients are presented with amoebic colitis while the rest manifested with extra-intestinal disease, most commonly as liver abscess [6]. The incidence and prevalence of amoebiasis vary in different part of the world [7]. The prevalence is increased in such a way that the newborn is now being reported with the infection [8].

The prevalence of infection caused by E. histolytica is very low in industrialized countries (about 1\%) and high in tropical countries (about 50-80\%) [9]. Clinical presentation of the intestinal infection may include abdominal discomfort, weakness, malaise, and constipation that may alternate with diarrhea, dysentery with the passage of exudates, blood and mucus, as well as colicky abdominal pain [10]. Systemic sign of infection includes fever, rigors, and polymorpho nuclear leukocytes while liver abscess results from infection through the intra-hepatic portal vessels [11]. E. histolytica infection is found in over $50 \%$ of the patients with acute diarrhea [12-14]. A study conducted in Egypt showed that $57.1 \%$ of the general patients with acute diarrheas were positive for the presence of E. histolytica [15]. On the other hand, similar study conducted in Saudi Arabia demonstrated that E. histolytica was found to be responsible for only $2.2 \%$ of acute diarrheas among children below 5 years of age [16]. The study was aimed to determine the prevalence of E. histolytica among children diagnosed with acute diarrhea in Kura General Hospital Kano.

\section{METHODS}

\section{Ethical clearance}

The ethical approval for the study with reference number MOH/off/797/ T.I/52 was obtained from Kano State Ministry of Health through Health Service Management Board Kano based on the consent of Kura General Hospital ethical committee.

\section{Study area}

Kura local area council is geographically located in the southern part of the state along Kano - Zaria road with a distance of about $35 \mathrm{~km}$ from the state capital. It is located at Latitude $11^{\circ} 46^{\prime} 17^{\prime \prime} \mathrm{N}$ and Longitude $8^{0} 25^{\prime} 49^{\prime \prime}$ E. It covers an area of about $206 \mathrm{~km}^{2}$ of land and population of about 144,601 according to 2006 census [17]. Kura Local Government shares common boundaries with Dawakin-kudu (East), Bunkure (South), Garun-Mallam (West), and Madobi Local Government (North) [17]. Kura is a rural communities inhabited by people whose predominant occupation is farming.

\section{Samples collection and examination of $E$. histolytica}

A total of 236 stools samples were collected from children (125 males and 111 females) within the age group of 0-5 years diagnosed with acute diarrhea attending Kura General Hospital Kano Hospital from February to August 2017 in clean, dry, and leak proof sterile bottle. The specimens were immediately transported to the Laboratory of Department of Biological Sciences Bayero University, Kano for examination of $E$. histolytica cysts and trophozoites. The stool samples were examined for E. histolytica cysts and trophozoites using direct wet 
preparation and Formol Ether concentration technique as described by Tanyuksel and Petri. [18].

\section{RESULTS}

Age and sex distribution of the participants

The age and sex distribution of the patients is presented in Table 1 . The distribution showed that the number of male patients (125) is higher than of the female (111). Patients of age category 4-5 years have the highest frequency with total of 51 subjects, followed by age category 2-3 years ( 50 subjects) and 3-4 years ( 49 subjects) while least subject was found among patients of less than a year (39 subjects).

\section{Prevalence of E. histolytica}

The prevalence of $E$. histolytica with respect to age and sex is presented in Tables 2 and 3. The result showed that age category 4-5 years has the highest prevalence with total of eight subjects which accounted for $3.39 \%$, followed by $2-3$ years and $3-4$ years 5 subjects each $(2.12 \%)$, $1-2$ years 3 subjects $(1.27 \%)$, and lowest frequency was found among patients of less than a year $2(0.85 \%)$. With respect to sex, higher incidence was found among males with total of 13 subjects which accounted for $5.51 \%$ while female has ten positive samples (4.24\%). The result is not statistically significant at $\mathrm{p}<0.05$.

\section{DISCUSSION}

The prevalence rate of E. histolytica among children age between 0 and 5 years in this study was found to be $9.75 \%$. Several studies on determination of the prevalence of E. histolytica were conducted worldwide [19-22]. The result of this study is in conformity with the result of Nyenke et al. [23] on prevalence of intestinal amoebiasis in infant and junior school children in Degema General Hospital and environs who found percentage prevalence of $11 \%$. This result also justifies the study of Memon et al. [24] who found the percentage of intestinal Amoebiasis in Children as $8.47 \%$. The prevalence of $9.75 \%$ in this study is within the prevalence range of $5-15 \%$ of all protozoan

Table 1: Age and sex distribution of the participants

\begin{tabular}{lll}
\hline Age (year) & Male (n) & Female (n) \\
\hline$<1$ & 20 & 19 \\
$1-2$ & 22 & 25 \\
$2-3$ & 28 & 22 \\
$3-4$ & 25 & 24 \\
$4-5$ & 30 & 21 \\
Total & 125 & 111 \\
\hline
\end{tabular}

Table 2: Prevalence of $E$. histolytica based on age

\begin{tabular}{lllll}
\hline Age (year) & $\begin{array}{l}\text { No. of } \\
\text { samples (n) }\end{array}$ & $\begin{array}{l}\text { Positive } \\
\text { samples (n) }\end{array}$ & $\begin{array}{l}\text { Prevalence } \\
\text { (\%) }\end{array}$ & p-value \\
\hline$<1$ & 39 & 2 & 0.85 & $0.528557^{\text {a }}$ \\
$1-2$ & 47 & 3 & 1.27 & \\
$2-3$ & 50 & 5 & 2.12 & \\
$3-4$ & 49 & 5 & 2.12 & \\
$4-5$ & 51 & 8 & 3.39 & \\
Total & 236 & 23 & 9.75 & \\
\hline
\end{tabular}

${ }^{a}$ Chi-square value is 3.1776 . The result is statistically not significant at $\mathrm{p}<0.05$. E. histolytica: Entamoeba histolytica

Table 3: Prevalence of $E$. histolytica based on sex

\begin{tabular}{lllll}
\hline Sex & $\begin{array}{l}\text { No. of } \\
\text { samples (n) }\end{array}$ & $\begin{array}{l}\text { Positive } \\
\text { samples (\%) }\end{array}$ & $\begin{array}{l}\text { Prevalence } \\
\text { (\%) }\end{array}$ & p-value \\
\hline Males & 125 & $13(56.5)$ & 5.51 & $0.616589^{a}$ \\
Females & 111 & $10(43.5)$ & 4.24 & \\
Total & 236 & $23(100)$ & 9.75 & \\
\hline
\end{tabular}

${ }^{a}$ Chi-square value is 0.2507 . The result is statistically not significant at $\mathrm{p}<0.05$. E. histolytica: Entamoeba histolytica infection as a causative agent of acute diarrhea as estimated by the World Health Organization. The result of prevalence rate of E. histolytica in the present study is higher than the reported prevalence of 4.2-6.5\% of $E$. histolytica infection in Bangladeshi children with diarrhea and also that of a Mexican study that found $8.4 \%$ of the samples to be seropositive for E. histolytica [25]. In Jordan, 8\% of the reported acute gastroenteritis cases are because of E. histolytica [13]. However, the result of this study is lower than a similar study from Colombia who reported $E$. histolytica to be responsible for $10 \%$ acute diarrhea in children [26]. On the other hand, finding of this study was contrary to that of McIver et al. [27] in Australia whose study did not find E. histolytica among children diagnosed with acute diarrhea. Several factors were responsible for the prevalence of E. histolytica in the present study, such factors include; poor drainage system, low standard of personal hygiene, and unhygienic method of sewage disposal.

Among the age categories in this study the children within age bracket of 4-5 years were highly infected, 8 (3.39\%). Higher prevalence among children in this group can be as result uncontrolled wandering around the street and other activities such as swimming. Low prevalence rate among subjects category of $<1$ year may be attributed to their innate resistance due to production of secretory immunoglobulin A that can minimize the adhesion between E. histolytica trophozoites epithelial cells, hence reducing new infection [28]. Findings from this study revealed that male children were more infected $(5.51 \%)$ than the female ones $(4.24 \%)$. However, the difference is not statistically significant $(\mathrm{p}<0.05)$. This is possible due to the reason that both gender are living in the same community and generally engaged in similar activities such as farming and hence exposed to similar hazard continually.

\section{CONCLUSION}

Based on the findings of this study, it is found that the percentage prevalence of $E$. histolytica among children diagnosed with acute diarrhea is $9.75 \%$. According to the study, more males are infected than the female but the result is not significant. Subjects of age category 4-5 years were found to be more infected. Factors such as unhygienic method of sewage disposal, poor drainage system as well as low level of personal hygiene contributed immensely to the distribution and proliferation of E. histolytica. It is recommended that creating the awareness for personal hygiene, proper sewage disposal and environmental sanitation should be encouraged.

\section{ACKNOWLEDGMENT}

The authors wish to acknowledge to the Kano State Government through Ministry of Health for the ethical approval. Thanks to the management staff of Kura General Hospital and staff of Biological Sciences Department Bayero University Kano for sample provision and use of laboratory facilities.

\section{AUTHORS' CONTRIBUTION}

All the authors have contributed equally in the research.

\section{CONFLICTS OF INTEREST}

All authors declared that no conflicts of interest exist.

\section{FUNDING}

None.

\section{REFERENCES}

1. World Health Organization. Readings on Diarrhea; Student Manual Programme for Control of Diarrheal Diseases. Geneva: World Health Organization; 1990.

2. Kreidl P, Imnadze P, Baidoshvili L, Greco D. Investigation of an outbreak of amoebiasis in Georgia. Euro Surveill 1990;4:103-4.

3. Harold WB. Entamoeba histolytica in Basic Clinical Parasitology 4. New York: Appleton-Century-Croft; 1975. p. 23-7. 
4. Farthing MS, Cavellos AM, Kelly P, Cook GC. Intestinal protozoa. In: Manson's Tropical Disease. $20^{\text {th }}$ ed. London: W.B. Saunder Company; 1996. p. $1255-67$

5. Ramasubramaniam V. Amoebiasis; 2008. Available from: http://www. webhealthcentre.com/diseasecondions/ameb.aspx. [Last accessed on 2009 Jun 19]

6. Guven A. Amoebiasis in the new born. Indian J Pediatr 2003;70:437-8.

7. Dialogue on Diarrheal; 1986. Available from: http://www.rehydrate. org/dd/pdf/dd27.pdf. [Last accessed on 2007 Feb 5].

8. Kaur R, Rawat D, Kakkar M, Uppal B, Sharma VK. Intestinal parasites in children with diarrhea in Delhi, India. Southeast Asian J Trop Med Public Health 2002;33:725-9.

9. Nesbitt RA, Mosha FW, Katki HA, Ashraf M, Assenga C, Lee CM. Amoebiasis and comparison of microscopy to ELISA technique in detection of Entamoeba histolytica and Entamoeba dispar. J Natl Med Assoc 2004;96:671-7.

10. Haque R. Rapid diagnosis of Entamoeba histolytica infection by using Entamoeba histolytica stool antigen detection kits. J Clin Microbiol 1995;33:2558-65.

11. Huston CD, Haque R, Williams A, Peter J. Molecular based diagnosis of Entamoeba histolytica infection. Experts Rev Mol Med 1999;1999:223-5.

12. Murray CJ, Lopez AD. Alternative projections of mortality and disability by cause 1990-2020: Global burden of disease study. Lancet 1997;349:1498-504

13. Haque R, Huston CD, Hughes M, Houpt E, Petri WA Jr. Current concepts: Amoebiasis. N Engl J Med 2003;348:1565-73.

14. Loshak D. Unexpectedly high prevalence of amoebic colitis among acute diarrhea patients in Egypt. Doctors guides review. Diagnosis of amoebic colitis by antigen, capture ELISA in patients presenting with acute diarrhea in Cairo, Egypt. Trop Med Int Health 2002;7:365-6.

15. Abd-Alla MD, Ravdin JI. Diagnosis of amoebic colitis by antigen capture ELISA in patients presenting with acute diarrhea in Cairo, Egypt. Trop Med Int Health 2002;7:365-70.

16. El-Sheikh SM, El-Assouli SM. Prevalence of viral, bacterial and parasitic entero-pathogens among young children with acute diarrhoea in Jeddah, Saudi Arabia. J Health Popul Nutr 2001;19:25-30.

17. National Population Commission. National Population Census Result. Abuja Nigeria: National Population Commission; 2006.

18. Tanyuksel M, Petri WA Jr. Laboratory diagnosis of amoebiasis. Clin Microbiol Rev 2003;16:713-29.

19. Pugh RN, Burrows SW, Bradely AK. Malumfashin endemic disease. Research project XVI, findings of a survey for Schistosoma mansoni, Hookworm, Girdiasis, E. Histolytica and nutritional status. Ann Trop Med Parasitol 1981;75:279-81.

20. Reynoldson JA, Behnke JM, Pallant LJ, Machnish MG, Gilbert F, Gilles S. Failure of Pyrantelin treatment of human Hookworn infections (Anclylostoma duodenale) in the Kimberly Region North West Australia. Acta Trop 1997;63:301-12.

21. Alaribe AA, Utsalo SJ, Gemade EL, Ejezie GC. Brine flotation (BF) as a standard technique for the detection of poly parasitism from stool. J Med Lab Sci 1994;4:16-20.

22. Agi PI. Comparative helminth infections of man in two rural communities of the Niger Delta, Nigeria. West Afr J Med 1997;16:232-6.

23. Nyenke C, Chukwujekwu DC, Stanley HO, Awoibi NK. Prevalence of intestinal amoebiasis in infant and junior school children in Degema general hospital and environs. J Appl Sci Environ Manage 2008;12:83-7.

24. Memon IA, Jamal A, Memon H, Parveen N. Intestinal amoebiasis in children and its effect on nutritional status. J Coll Physicians Surg Pak 2009;19:440-3.

25. Katz DE, Taylor DN. Parasitic infections of the gastro-intestinal tract. Gastroenterol Clin North Am 2001;30:797-815.

26. Urbina D, Arzuza O, Young G, Parra E, Castro R, Puello M. Rotavirus Type A and other enteric pathogens in stool samples from children with acute diarrhea on the Colombian Northern coast. Int Microbiol 2003;6:27-32.

27. McIver CJ, Hansman G, White P, Doultree JC, Catton M, Rawlinson WD. Diagnosis of enteric pathogens in children with gastroenteritis. Pathology 2001;33:353-8.

28. Barbosa-Sabanero G, Avila E. Recognition of Entamoeba histolytica IIS, KDA surface protein by human secretory immunoglobulin from asymptomatic carriers. J Parasitol 2004;90:373-82. 